\title{
Adultism at the Root of Youth Maltreatment in A. S. King's Still Life with Tornado
}

\author{
Nourhene Dziri ${ }^{1}$ (1D
}

Accepted: 2 December 2020 / Published online: 24 January 2021

(c) The Author(s) 2021

\begin{abstract}
While child abuse and neglect have been explored at length, less attention has been paid to the role of contemporary realist Young Adult Literature (YAL) in denouncing abusive treatments of young people in conjunction with adultism. It is hereby suggested that age inequality is at the core of youth maltreatment, and it is this intersectionality that should lead attempts to confront this global problem. YAL offers a bottom-up approach to deal with these social issues through first-hand experiences of oppressed, yet cognizant protagonists. This article foregrounds the voice of Sarah, the lead character featured in A. S. King's Still Life with Tornado (2016), in addressing the drastic outcomes of ageist stereotypes at the family level. The emphasis on the perspective of young people provides an informative understanding of youth subordination, parental power, and adultist discrimination in an effort to challenge such practices.
\end{abstract}

Keywords Adultism - Intergenerational relationships · Youth maltreatment · Young adult fiction · Parenting

\section{Introduction}

Youth maltreatment is a complex issue that takes place under different forms pertaining to physical, emotional and psychological abuse and at different levels- the national, the structural, the familial and the individual. Despite the joint efforts of the World Health Organization (WHO) and the ratification of the United Nations Convention on the Rights of the Child by 196 countries, the prevention of abusive acts against children and young people is still at an early stage. Thanks to its wide accessibility, contemporary realist Young Adult (YA) literature performs a crucial role in providing examples offering insight into the issue of child abuse and how to prevent it. This type of literature raises awareness among adult

Nourhene Dziri

nourhene.dziri@stu.mmu.ac.uk

1 Department of English, Manchester Metropolitan University, Manchester, UK 
readers (constituting half the readership of the genre) (Kitchener, 2017) and young readers alike about the causes and consequences of youth oppression, all the while encouraging younger audiences to learn about their rights and exercise them along with their responsibilities. In its examination of A. S. King's Still Life with Tornado (King, 2016), this article recognises that youth maltreatment is largely due to conceived adultist ideas about young people. This intersection emphasises intergenerational relationships at the family level with a special focus on the parental-protection versus control paradox. It argues for the urgency to disrupt adultist stereotypes for young people depicting them, for example, as rebels, or as burdensome children or passive victims, which then tend to justify their maltreatment under the pretext of discipline. Moreover, this article highlights the conjunction of discriminatory systems of adultism and sexism through the nuances in the upbringing of boys as opposed to girls and the dominance of the father.

The analysis conducted hereafter on King's narrative sheds light on the underlying connection between youth maltreatment and adultism which has not yet been explored at length. Before delving into this interpretive reading of Still Life with Tornado, this article reviews prior understandings of adultism along with the tensions and correlations amongst previous work on this area of study. In her interpretation of the term, Hava Rachel Gordon acknowledges "age as an axis of social inequality" (2007, p. 632) between adults and young people. This inequality is based upon generated stereotypes about children and adolescents placing them as the target group of a type of discrimination that is known as adultism (ageism against young people).

Holding adolescents at the receiving end of this stigmatisation, Nancy Lesko unravels the workings of adultism through the "accepted ideas about adolescence [which] were initially developed, codified, circulated, and popularised" (2012, p. 4). These social constructions of youth are predominantly derogatory stereotypes depicting youth as lazy, immature and up to no good, or even as "synonymous with crazed hormones, as delinquents, deficiencies, or clowns, that is, beings not to be taken too seriously" (Lesko, 2012, p. 2). Similarly, Elisabeth Young-Bruehl suggests that the spreading of pejorative perceptions of children help define the concept as, "a belief system that constructs its target group, 'the child,' as an immature being produced and owned by adults who use it to serve their own needs and fantasies" (2012, p. 36). However, she specifically uses the term childism instead of ageism or adultism. Her reasoning is that childism is likened to other forms of prejudice such as sexism, racism and other -isms, and should therefore hold a place in prejudice studies (Young-Bruehl, 2012, p. 18).

In contrast, John Wall argues that Young-Bruehl's word choice robs the movement of youth empowerment of its essence through the focus on the negative connotation that is the mere act of discrimination against young people (2019, p. 7). Similar to the feminist movement, Wall believes that childism as a concept should involve the activist agenda challenging adultism instead of establishing an additional synonym entailing youth subordination (2019, p. 7). Still, despite the underlying disagreement on the terminology, both the works of Young-Bruehl and Wall along with earlier works of Peter Hunt (1989) and more recent publications by Marah Gubar (2009), Jack Zipes (2012), David Rudd (2013), Clémentine Beauvais 
(2015), Michelle Superle (2016), and Vanessa Joosen (2013) demonstrate a clear shift towards the disruption of the widespread prejudice against children.

Scholars today are starting to denounce prejudiced outlooks concerning young people based on age inequality. For example, Michelle Superle establishes a contemporary model of childhood which "envisions children as active participants contributing to their society" (2016, p. 145) to reform children's literature criticism. Her choice of words to describe young people such as "empowered," "active," and "participants" (2016, p. 145) emphasises the sophistication of this current vision of childhood in contrast with preceding demeaning depictions and ageist stereotypes. While Grimms' fairy tales like "Hansel and Gretel" (1812) presented sexist and adultist plots (Zipes, 2012, p. 7), today's children's literature and young adult fiction reflect this change through the portrayal of cognizant young protagonists such as Harry Potter or Katniss Everdeen from the Harry Potter- (1997-2007) and The Hunger Games (2008-2020) series respectively. This is why Jack Zipes interrogates the reasoning behind old tales like "Hansel and Gretel" which suggests that "the children should return to their father with a treasure and not question or reject him when he has played a negative role in their lives by abandoning them" (2012, p. 7). Zipes' interpretive reading criticizes the credulous servitude of the two young characters to their father regardless of his deeds. However, contemporary young adult characters like Harry Potter and his friends Hermione Granger and Ron Weasley are distinguished for their critical abilities and active roles not only in their personal lives, but in society as well.

Contemporary realist Young Adult (YA) fiction more specifically reveals entrenched adultist parenting through the voice of abused yet empowered young protagonists. Amber Moore attests to this powerful literary tool in writing that "children's and YA literature is an important arena for exploring different ideas about oppression and empowerment, and considering how different forms of childism impact youth" (2018, p. 162). Indeed, narratives like The Sun Is Also a Star (2016) and The Hate U Give (2017) provide an informative insight into intergenerational relationships through their realist interpretations of contemporary social behaviours such as family relationships. Moreover, considering the age of the protagonists as well as the targeted audience, the child's pro-active role is emphasised in these stories. Accordingly, there is a recurrent depiction of the conflictual relationship and the misuse of power by controlling adults against activist children striving for social justice.

A prominent example that considers the power of adults in YA literature is A. S. King's Still Life with Tornado (2016). The novel revolves around a family of four, comprised of Sarah and Bruce, daughter and son of Helen and Chet. Told from the perspective of Sarah, an adolescent female protagonist, this powerful narrative stands out in its examination of ageism through an account of its cyclical, intersectional and detrimental impacts on both the micro- and macro levels of individual and familial experiences. It reflects the interlocking of oppressive systems, namely sexism and ageism, resulting in the abuse and manipulation of the spouse Helen, the ongoing physical maltreatment of the older son Bruce, and the indirect yet drastic existential crisis of the younger daughter Sarah. At a time when all this abuse is perpetrated at the hands of the husband and father Chet, the 
author reveals that the latter is himself the victim of child maltreatment emphasising in addition to the long term inflicted mental and physical health problems, the lingering effects of ageism and maltreatment from victim to abuser. This article uses King's text to consider the aforementioned dynamics as consequences of adultist and sexist prejudices which often result in abusive parenting of young people either deliberately or in an indirect manner.

This article examines the transition of ageist prejudice from a popularised social construction into direct and indirect acts of maltreatment whereby the disruption of the latter is contingent on that of the former. In fact, DeJong and Love identify adultism not only as a discriminatory belief system against young people such as discussed above by Lesko and Young-Bruehl, but as an act of oppression in itself and so they move to use the term adultism interchangeably with youth oppression (2015, p. 490). This is not the only study where the two concepts are interwoven into one. Note that Genia M. Bettencourt simply uses the "oppression of those under the age of 18 " (2020, p. 155) as a definition of adultism. While this article also attests to the parallels between adultism and youth oppression, it primarily complicates the underlying rationale of equivalence between the two by reflecting how one engenders the occurrence of the other. By doing so, I recognise that adultism operates at varying degrees, some of which are subliminal and do not necessarily result in overt violent acts of abuse, but could impede the development of young people nonetheless. The purpose of this examination is to call for the need to assess this analogism as a key factor in the battle against both physical and emotional child maltreatment.

Abuse of young people at the hands of their own parents and caregivers is an intricate issue because it happens within the private familial context. It is different from structural and other forms of abuse because it is carried out by those who are entrusted with providing all the love and care for the abused. The World Health Organisation points to the intricacy behind this paradox by emphasising the "particular difficulties when designing strategies for prevention and victim services, since the perpetrators of the maltreatment are at the same time the source of nurture for the child" (2006, p. 7). For this reason, without youth awareness about their rights as the first step aiming towards the disruption of their maltreatment, adultist parental controls have a wider potential. It is in this sense that YA literature performs a crucial role in spreading knowledge about children's rights, youth resilience, empowerment and activism. Considering this literature's reach amongst its young readers, Desmond Manderson distinguish that "the texts that play this important role are not the Magna Carta or Marbury v. Madison. They are our children's books" (2003, p. 93). Children's and young adult narratives allow readers to safely explore situations of abuse from different viewpoints (Smith-D'Arezzo \& Thompson, 2006, pp. 336-7; Strimel, 2004, p. 37). Moreover, they do not only contextualise children's rights as stated in the UN convention, but also the ways they are violated. Indeed, "children[s] literature" according to Manderson, "is not a source of information about social structures of subjectivity in our society. It is the very site of their emergence. Children's literature is not a series of texts about the law. It is a source of law" (2003, p. 93). It is this contextualisation of law and various social interactions between relatable characters which highlights its importance. 
Indeed, novels such as King's Still Life with Tornado show how easily adultist behaviours can be carried out within the home. Hence, using King's text helps to understand the physical damage inflicted on Bruce and the damage to the mental health of his sister Sarah, as consequences of their parents' adultist viewpoints. Moreover, in its advocacy of equal power dynamics between youth and adults at the family level, this article considers another system of inequality, i.e. sexism. Still Life with Tornado draws out the intersection of adultism and sexism in the upbringing of the two children, resulting in different yet detrimental forms of oppression. The treatment of Bruce in King's novel demonstrates how adultism leads parents to take advantage of their authoritative role as caregivers to hurt their own children. Bruce becomes representative of a case known by Doyle and Timms as "the Cinderella syndrome" (2014, p. 83), whereby children "may be singled out [for abuse] because they have the role of family scapegoat" (2014, p. 89). In other words, in family environments like Bruce's, the abusive parents do not treat their children equally as the abuse falls typically on a specific child-target. Indeed, Sarah admits their parents' biased treatment of her brother confessing that "I'd seen that look before and I'd heard Dad be rude to Bruce before and I felt bad right then for telling Bruce to shut up. I guess I was just used to everyone ragging on Bruce. It was a tradition in our family" (King, p. 238). The word "tradition" emphasises at once the ongoing recurrence of Bruce's sufferings, and the regularity that makes the abuse appear almost mundane. Young-Bruehl links this outlook on abuse to adultism asserting that it is "how harm to children is rationalized, normalized" (2012, p. 6). In this regard, due to the spread of ageist beliefs depicting youth as "a danger to be suppressed" (Manderson, 2003, p. 94), acts of discrimination become widely accepted even at the hands of one's own parents.

Authors of YA literature resort to the portrayal of empowered characters voicing an articulate sense of agency (like Sarah and Bruce from King's novel) in order to spread awareness about adultist conduct. This brother and sister demonstrate an acute responsiveness to the coercive parenting power within their family which ultimately drives Bruce away for six years without a single contact. Once Sarah reaches him after all this time, he still recalls his father's adultist manners admitting to her:

Dad hit me a lot. If you count slapping and hair pulling, then it was everyday sometimes. (King, p. 209)

In this example, the author interrogates what Zipes condemns as "the right of adults to discipline children severely according to principles that justify their arbitrary power over the young" (2012, p. 6). On another occasion, King portrays a scene of similar abuse witnessed by ten-year-old Sarah and Helen. Sarah recounts the maltreatment of a child by her mother at a public place:

"You can't act like that at a restaurant!" Slap. "I told you to be good tonight!" Slap. "You need to behave, Julia!" Slap. [...]"

“She was probably, like, two years old.” (King, p. 96) 
The author demonstrates what Miller refers to as "hurtful parenting" whereby parents maltreat their children while claiming to teach them alleged "decency and morality" (Miller, 2006, p. 37). In cases like these, ageism leads some adults to abuse young people in order to establish adult supremacy, which goes hand in hand with youth subordination. In this sense, adultist behaviours become the driving force turning parenting into pervasive authoritative maltreatment under the pretence of discipline.

Even though Sarah is spared the physical violence experienced by her older brother, she still falls victim to a different form of abuse also resulting from the intersection of parental ageism and sexism. Whereas Bruce is looked upon as a dangerous threat by his father (to the point where Bruce is prohibited from contacting his sister with police intervention threats if he does not comply) (King, p. 208), Sarah symbolizes earlier stereotypes linking childhood to "an isolated emblem of innocence" (Gubar, 2009, p. 4). Helen's resort to deceit in order to maintain Sarah's innocence is obvious when she addresses Bruce, saying:

She's ten, [...] Can't you just pretend to have a good time? (King, p. 27)

These different parental attitudes towards Sarah and Bruce emphasise gender discrimination in Helen and Chet's parenting style. Indeed, Lipowska et al. assert that "during childhood, parents or caregivers are the first and the most important people who provide a base for the creation of gender stereotypes among children" (2016, p. 226). Best-selling author and behavioural investigator Vanessa Van Edwards also refers to the impact of this sexist upbringing at an early age as a form of gender programming for young people to follow in their adult life $(2019,26: 44)$. Accordingly, the development of young people is directly influenced by gender role models around them. For this reason, the examination of the role played by parents and caregivers in literature aimed at adolescents is significant, given that it will either reinforce or challenge the young reader's experiences within their own family unit. Still Life with Tornado instantiates how gender, in conjunction with adultism, plays a decisive role in the displayed parenting treatment of boys and girls.

Ageist perceptions of young people encourage the acceptance of youth subordination in societies leading to the justified manipulation of subservient children at the hands of their parents under the youth politeness pretext (Alice Miller, 2006, p. 37; Young-Bruehl, 2012, p. 37). The archaic adultist perception of Sarah leads Helen and Chet to keep her outside of the abuse occurring within the family to preserve the symbol of innocence which she represents. For instance, they refer to each other as Mom and Dad in front of her but use their names when she is not around which she finds to be rather "annoying" (King, p. 12). This becomes symptomatic of a much deeper and more problematic level of deceit, as Helen admits "Chet and I have been lying to her since she was born" (King, p. 156). There are prejudicial motivations behind this parenting behaviour. Young-Bruehl recognises that all forms of prejudice are "inherently self-justifying" (2012, p. 22), and for this reason:

People have motivations, and they have beliefs that justify their motivations and their actions. Those parental motivations and prejudices lodge in their 
children along with the physical blows and attacks or the verbal blows and emotional attacks. (2012, p. 104)

As part of her parental motivations, Helen attempts to rationalise their deceitful treatments of their daughter. This manifests itself as a denial where Sarah's brother, Bruce, is a victim of violence but it is also implicit in the pretence that the parents are part of the functional nuclear family, seen in the way they name each other "Mom" and "Dad". Helen's belief that her actions are justified are seen when she confesses "but we wrecked Bruce. I didn't want to wreck Sarah, too" (King, p. 51). In this sense, it becomes clear that "even well-meaning adults can be childist [adultist]" (Joosen, 2013, p. 212). However, whilst Helen aims to protect Sarah from the harsh reality of their family's physical abuse, these lies ultimately drive her daughter to an existential crisis at the age of sixteen.

King's narrative portrays how child maltreatment occasionally occurs unintentionally, as part of an attempt at protecting the child. However, regardless of the good intentions of Helen and Chet vis-à-vis the upbringing of their daughter, the adultist perception of Sarah as the innocent child leads them inadvertently to cause more psychological damage. Indeed, "given this widespread prejudice," Jack Zipes affirms that "almost every adult in America tends to act against children while thinking that he or she is actually doing what may be best for the child. In other words, we all live in a contradictory relationship with children" (2012, p. 8). I agree with Zipes that adultism, not only in America but also in different parts of the world, is so widely spread as a belief system that means adults unconsciously act accordingly. However, the example from King's narrative indicates that subliminal adultist treatments do not always imply less harm to young people as opposed to overt physical violence. Indeed, Sarah's existential crisis resulting from the parents' attempts at hiding the truth about their failed marriage and familial abuse endorses the idea that over-shielding can come at a cost. Similarly, Donovon Ceaser talks about how overprotection occurs as a means of youth subordination (2014, p. 169). Hence, King conveys the threat to young people's mental health prompted by adultist beliefs besides blatant physical maltreatment.

Helen explains to Sarah that they meant well by telling her:

"We didn’t want you to suffer," she says. "We made a deal." (King, p. 252)

Ironically, Sarah's suffering is the undeniable outcome of that deal they supposedly made to shield her. The young protagonist's circumstance comes under what Doyle and Timms distinguish as "The Emotional Abuse of "Non-Abused' Siblings" (2014, p. 86). On this subject, they affirm that, "another particularly vulnerable emotionally abused group are children who are in families where they are not directly attacked, but daily witness the abuse of siblings" (Doyle and Timms, 2014, p. 61). To avoid this happening, Helen and Chet require Sarah to overlook instances where Chet beats his wife, or his son, such as when Helen locks her on the balcony during their vacation in Mexico when she was ten years old. Sarah's abuse is of the emotional kind because she could still hear all the fighting through the door (King, p. 239). King here emphasises that in addition to direct forms of abuse, an adultist approach would recognise that despite well-meaning parental intentions, abuse is 
still indirectly carried out. Hence, the mother's reflection on the agreement she made with her husband to protect their daughter can be read in the lens of an adultist approach. Indeed, Helen reconsiders the parenting deal asserting that "since Sarah left school, I realized that every single day that goes by with me playing my part in the deal and Chet playing his part in the deal is a step toward Sarah taking shit she doesn't deserve" (King, p. 110). Here, the mother's apologetic tone indicates an awareness regarding the disadvantageous treatment of Sarah. Moreover, the character's use of the informal phrase taking shit emphasises Helen's deep regret. What this reflection also suggests is a yearning to break free from this deal.

Helen continues to admit that "people pleasers make the best victims" (King, p. 110) denoting that she mainly approved of the deal to please Chet. Through the depiction of Chet's abuse of his wife in addition to that of the children, the author insists once more on the correlation of the two discriminatory systems of sexism and adultism. In fact, earlier in the narrative, the young protagonist reveals her father's control over Helen vis-à-vis her parenting explaining that:

He's a fanatic about maintaining façade and building envelope integrity. He knows all about code and how our kitchen bathroom does not meet code because it's too small. I do not meet code because I'm not going to school. Mom doesn't meet code either because they made a parental deal and she's not keeping up her side of the bargain. (King, p. 11)

King emphasises the workings of sexism as Helen constantly finds herself compelled to follow Chet's plans. The words façade, envelope integrity and code are direct references to Chet's parenting style. They allude to the lies imposed on Sarah as a means to hide the abuse instead of putting an end to it. Lying to Sarah is Chet's way of dealing with his issues, but only at the surface level because the maltreatment of Helen and Bruce persists even if it is carried out in secret. It is this lying and abuse which prompts Sarah's mental health crisis.

The intersection of sexism with adultism continues in the depiction of the nature of Sarah's emotional and psychological maltreatment. Sarah admits the need to "make up another story right there and right then when I was sitting on that balcony by myself with my sunburn and looking out into the sea where the sea god had no idea how to help me" (King, p. 240). This confession reveals the workings of Chet's parenting as Sarah is compelled to un-see what she sees and unhear what she hears. Doyle and Timms further explain this asserting that "the 'non-abused' children are in fact being emotionally abused. First, they are likely to be living in fear, although this will be deeply repressed" (Doyle and Timms, 2014, p. 86). Accordingly, at a time when the parents think they are protecting Sarah, they are in fact urging her to repress a multitude of incidents, fears and emotions.

King stresses the negative outcome of this manipulative parenting habit as Sarah's emotional and psychological health is driven to the edge as a result. By means of magical realism, King depicts the sixteen-year-old protagonist's eventual mental breakdown through the latter's interractions with her other selves-ten-year-old Sarah, twenty-three-year-old Sarah, and forty-year-old Sarah. When updating Bruce on her current situation six years after he was kicked out, Sarah admits "I don't want to tell him it's a mental health break because even though I know that breaking your 
brain is the same as breaking your arm, I'm still ashamed that my brain is broken" (King, p. 175). Hereby, the author emphasises similarities between the direct physical abuse of Bruce and the circumstantial emotional and psychological abuse of Sarah. Both arise from adultist parenting and result in harming children and young people. Indeed, the Child Welfare Information Gateway (CWIG) establish the detrimental impacts of child abuse on behavioural and emotional functioning confirming that "just as positive experiences can assist with healthy brain development, children's experiences with child maltreatment or other forms of toxic stress, such as domestic violence or disasters, can negatively affect brain development" (2015, p. 5). This unfavourable outcome on brain development is demonstrated through Sarah's exisistential crisis.

Amongst several negative effects of child maltreatment on the brain, Sarah reveals what is known as "Increased Internalizing Symptoms" (CWIG, 2015, p. 8). According to Roger J. R. Levesque, the latter refers to "problems of withdrawal, somatic complaints, and anxiety/depression" (2011, p. 13). These can all be identified within the novel: Sarah's behaviour shows signs of withdrawal when she decides first to stop drawing because art does not seem to be original to her anymore (King, p. 2), and also when she drops out of school without giving any explanation (King, p. 3) despite the insistence of her parents on the importance of education. Furthermore, King foregrounds her protagonist's depression through a bleak narrative tone which can be identified when Sarah recounts while referring to her parents, "I don't think they love each other. I don't think they even like each other. I can't figure out what to think about this, but I feel instantly lonely" (King, p. 57). Another prominent example is her assertion that she "was alone and life meant a little less than it ever would mean again" (King, p. 240). Through this thorough characterization of Sarah, King sheds light on the brutal consequences of adultist prejudice regardless of the abuser's intentions or the degree of the abuse. Correspondingly, Herringa et al. confirm that "maltreatment in childhood, even at the lower severity levels found in a community sample, may alter the regulatory capacity of the brain's fear circuit, leading to increased internalizing symptoms by late adolescence" (2013, p. 19,119). For this reason and many others, child maltreatment which is "recognized internationally" by the WHO "as a serious public health, human rights, legal and social issue" (2006, p. 7) ought to be disrupted at its core.

Sarah's internalizing symptoms are closely linked to the continual repression of bad incidents and feelings throughout her childhood prompted by the deal Chet imposed on Helen. On this note, Miller establishes that:

Frequently, physical illnesses are the body's response to permanent disregard of its vital functions. One of our most vital functions is an ability to listen to the true story of our life. [...] the conflict between the things we feel - the things our bodies register - and the things we think we ought to feel so as to comply with moral norms and standards we have internalized at a very early age. (2006, p. 19)

To instantiate this diagnosis, Sarah's mental health deterioration illustrates her body's reponse to the constant emotional and psychological abuse she endured for several years. Hence, she grew up with a compelling urge to deny the harsh reality in 
front of her eyes and to comply to the parental deal with all the lies and manipulations. This created a constant need to pretend and make up stories to the point where she could no longer remember things accurately. It is for this reason that ten-yearold Sarah reminds her present sixteen-year-old self of her disregarding tendency when she fails to recollect memories, saying:

"You probably blocked it out. It was bad." (King, p. 33)

King here demonstrates what Miller identifies as the response of the body. Accordingly, Sarah becomes so accustomed to the habit of overlooking incidents in the course of time, that she now does it impulsively without even realising it.

The authoritarian controlling of Sarah led Chet to decide what she can and cannot bear to see, to know or to deal with. The source of this exploitation of the daughter is the ageist belief that Young-Bruehl explains as:

children are by nature meant to be owned by their male parent and that they lack reason has justified treating them like slaves and like immature, unformed persons without the active qualities, the developmental thrust, the proto reasoning and choosing, and the individuality that contemporary developmentalists now recognize in them. (2012, p. 25-26)

This adultist prejudice leads Chet to attribute to his daughter traits of vulnerability and passivity. However, Marah Gubar affirms that "viewing children as deficientas unable to grasp certain concepts or skills — can help produce the very incapacities we claim merely to describe" (2013, p. 451). Accordingly, it is this underestimation of children and their aptitudes which inhibits their development.

The ageist outlook identifying young people as "incomplete beings on the path to adulthood" (Smith, 2011, p. 23), installs in them negative habits which lead to further their subordination. Hence, the adultist upbringing of Sarah instigates her urgency to repress her issues and replace them with other thoughts which ultimately creates a handicap in her brain functions. King emphasises this impairing outcome within Sarah's difficulty to differentiate between genuine happenings and her mind's creations. For this reason, she is unable to tell whether or not the other versions of herself that she meets now and then are objects of her imagination. This impediment to remember things accurately leads the protagonist to a state of confusion due to what Miller identifies in her suggestive title as the Lingering Effects of Hurtful Parenting (2006). Bruce recognises their parents' prejudices and faults vis-à-vis Sarah when he bluntly admits to his sister:

"They put you in a role and you had to play that role,"

to which Sarah replies:

“That's the problem, I'm acting." (King, p. 212)

Through these words, King shows how adultism influences parents to rob their infants of their life and full potential by manipulating them into impersonating who they want them to be. 
Still Life with Tornado further attests to the malicious continuity of the lingering effects of hurtful parenting in the way that previously abused children become adultabusers. Helen admits to her daughter the ongoing circle of abuse in an attempt to justify her husband's behaviour by saying:

"So, he had a rough childhood. He does what he can." (King, p. 194)

Hence, her recognition that Chet's abusive character is a result of being himself maltreated as a child is a clear assertion of her awareness about the long-lasting effects of child maltreatment which only raises questions about why she has brought her daughter up in an environment of lies and deceit. Sarah hints at this irony as she interjects "He does what he can, my ass. A minute ago she denied Dad even hit Bruce" (King, p. 194). Through this exchange between mother and daughter, the author emphasises the coercion of adultism which not only legalises child maltreatment, but also stimulates abused children to perpetrate the same harm they endured upon their children in the future. The WHO sheds light on this vicious perpetuity of child maltreatment in asserting that:

The consequences can also last a lifetime. Adults who were abused or neglected as children have a higher risk of: Perpetrating or being a victim of violence, Depression, Obesity, High-risk sexual behaviours and unintended pregnancies, Harmful use of tobacco, drugs, and alcohol. (2017, p. 4)

This declaration reaffirms the need to disrupt child maltreatment at its roots to avoid it further spreading from generation into another. For this reason, it is crucial to look at how children and young people conceive of this particular issue.

The examination of youth perspectives on the matter of ageism and child maltreatment is crucial in the identification of the subtle adultist behaviours which are just as harmful as obvious physical violence. In fact, indirect ageist abuse is so intricate in comparison to physical aggression to the point where Zipes admits that, "we are all to a greater or lesser degree guilty of childism" (2012, p. 8). It is this subtlety behind indirect emotional and psychological abuse which allows it to spread to a great extent. In her novel, King raises her readers' awareness about the detrimental, yet understated impacts of indirect maltreatment. Being herself a victim of the latter, Sarah maintains that "The absence of violence is not love" (King, p. 257) in opposition to Chet's defensive assertion: "I still don't hit you!" (King, p. 257) to Helen when she eventually asks him to leave the house. King attempts to transmit the idea that physical harm is not the only destructive force because ageism also operates on a psychological level. In line with the author's message, Young-Bruehl suggests that adultism is the equivalent of the subjugating perception of young people as the property of their parents (2012, p. 5). Hence, she specifies that "People do not always hate those they subordinate; but those they subordinate with an "ism," a prejudicial political ideology, they cannot love" (Young-Bruehl, 2012, p. 5). Young-Bruehl believes that this particular type of discrimination against young people prevents all affinity between adults and young people because of all the harm it entails. Accordingly, these ageist beliefs create an intergenerational animosity which cannot make way for love and acceptance without the disruption of these prejudices. 
YA literature performs a crucial role in exposing behaviours deemed to be ageist that we might otherwise consider protective, such as in the case of Helen. When the latter tells her daughter: "You're sixteen years old", Sarah perceives this assertion to stem from a condescending ageist standpoint. Displeased by her mother's disdainful manner, the young protagonist demonstrates a discernible mindfulness of ageist discrimination as she avows "I am sixteen, I am ten, I am twenty-three, I am forty. After last night with Bruce, I understand everything." Here, Sarah discredits social hierarchies based on age recognising that ten, sixteen, twenty-three or forty are but the different stages of life that humans gradually experience. And from that, she retorts defiantly to her mother concerning her current age: "That doesn't make me stupid." (King, p. 231) Accordingly, this interaction establishes how adults discriminate against youth based on their young age and how the targets of this prejudice discern such behaviours to be antagonistic. Therefore, it is a primary concern to dissect this pervasive perception of young people as inferiors instead of confrères to their older counterparts in order to alleviate intergenerational conflicts denying children of parental care.

It is also important to consider how ageism at the family level operates in conjunction with other forms of prejudice such as sexism to establish a strong basis for the movement of youth empowerment. Gordon, a specialist in the social construction of inequalities, affirms that "youth activism cannot be understood through a generational lens alone" (2008, p. 52). Instead, she forgrounds the need to examine the intersection of different forms of discrimination that helps building a stronger case (2008, p. 52). Gordon then explains how ageism and sexism proceed in parallel maintaining that:

Parents often expect a measure of independence and even defiance from their sons that they do not expect from their daughters. Indeed, parenting patterns can promote boys' independence and autonomy and girls' interdependence, dependence, and/or passivity. (2008, p. 34)

These widely spread ageist and sexist stereotypes are also discernable in Still Life with Tornado. Indeed, Bruce recognises the difference between how he and his sister are treated by Helen and Chet as he declares that: "It's like we had two completely different sets of parents.” (King, p. 209) This revelation explains why unlike Sarah, Bruce is brutally abused by their parents.

Another example of ageism and sexism operating in relation to one another in King's narrative is seen through the impact they have on the young protagonist. To raise this concern, King draws once more a parallel between sexism and the type of maltreatment Helen and Chet carry out to each of their children. For this purpose, Sarah voices her apprehension about the sufferings of her brother while repressing her own because they are not as direct. Accordingly, she reflects:

"How do I even bring it up in the middle of a conversation that includes both my mother getting her bones broken and Bruce getting hit every day of his life until I was born? It just makes me feel the pervasive feeling of being sixteen-silly and dramatic. It's not a long story. It's an unimportant story." (King, p. 211) 
In this example, Sarah denounces one more stigma about teenage girls in particular, i.e., silly and dramatic and its impact on her. Indeed, this judgemental outlook on young women urges Sarah to dismiss her own pain despite its severity on her mental health in order to dismantle this ageist and sexist stereotype. King directs attention to the complex issues raised by the connection between ageism and sexism which has not yet been researched at length. Hence, future research on the topic of ageism could benefit from an elaborate exploration of ageism in relation to not only gender, but also race and class power dynamics to reinforce youth activism.

\section{Conclusion}

The examination of King's YA narrative Still Life with Tornado provides insight into a deeper issue of age discrimination. Adultism is hereby identified as the main source for direct and indirect abusive parenting. Different stigmas on young people have been established, perceiving what David Rudd knows as "the problematic figure of the child" (Rudd, 2013, p. 3) either as a dangerous threat to be tamed, a symbol of purity to be preserved, or a submissive character to be manipulated. It is also recognised that other forms of prejudice such as sexism are at an interplay, thus further subjugating this target group of youth. The novel draws attention to the ways that parents might consciously or unconsciously abuse their children leading to detrimental physical and psychological health problems. The novel suggests that when paired with adultist approaches, parenting can become a destructive force of authority and control which is justified by using the purported excuse of discipline and/or protection. In its exploration of adultist parenting, this article attests to the crucial role of young adult fiction in denouncing this coercive issue occurring in the intimacy of households. It is in this sense that "fiction and nonfiction," as Joosen puts it "can go hand in hand to give insight into childism and to offer alternatives for it, for the benefit of children and adults alike" (2013, p. 215). YA literature features empowered young protagonists offering an informed perspective into how young people conceive of ageist prejudices, statements and behaviours. Indeed, Zipes indicates that "we [as adults] dictate what they should learn and how they behave without listening to their needs and wants and without paying attention to their developmental capacities" (2012, p. 8). This is why it is imperative to listen to what young people have to say on the subject to obtain an informed viewpoint on how to put an end to adultism and thus child maltreatment not only at the family level but as a societal problem.

Acknowledgments I would like to thank my supervisors, Dr. Nicola Bishop and Dr. Blanka Grzegorczyk, for their valuable feedback on this paper.

Funding No funding was received to assist with the preparation of this manuscript. 


\section{Compliance with ethical standards}

Conflicts of interest The author has no relevant financial or non-financial interests to disclose.

Open Access This article is licensed under a Creative Commons Attribution 4.0 International License, which permits use, sharing, adaptation, distribution and reproduction in any medium or format, as long as you give appropriate credit to the original author(s) and the source, provide a link to the Creative Commons licence, and indicate if changes were made. The images or other third party material in this article are included in the article's Creative Commons licence, unless indicated otherwise in a credit line to the material. If material is not included in the article's Creative Commons licence and your intended use is not permitted by statutory regulation or exceeds the permitted use, you will need to obtain permission directly from the copyright holder. To view a copy of this licence, visit http://creativecommons.org/licen ses/by/4.0/.

\section{References}

Bettencourt, G.M. (2020). Embracing problems, processes, and contact zones: Using youth participatory action research to challenge adultism. Action Research, 18(2), 153-170. https://doi. org/10.1177/1476750318789475.

Beauvais, C. (2015). The Mighty Child: Time and Power in Children's Literature. Amsterdam/Philadelphia: John Benjamins Publishing Company.

Ceaser, D. (2014). Unlearning adultism at Green Shoots: a reflexive ethnographic analysis of age inequality within an environmental education programme. Ethnography and Education, 9(2), 167-181. https://doi.org/10.1080/17457823.2013.841083.

Children's Bureau. (2015). Understanding the Effects of Maltreatment on Brain Development. Retrieved June 13, 2020, from Child Welfare Information Gateway: https://www.childwelfare.gov/pubPDFs/ brain_development.pdf

DeJong, K., and Love, B.J. (2015). Youth oppression as a technology of colonialism: Conceptual frameworks and possibilities for social justice education praxis. Equity and Excellence in Education, 48(3), 489-508. https://doi.org/10.1080/10665684.2015.1057086.

Doyle, C., and Timms, C. (2014). Child Neglect \& Emotional Abuse: Understanding. Assessment \& Response, https://doi.org/10.4135/9781473919716.n6.

Edwards, V.V. (2019). How to Be More Likeable and Impressive I Vanessa Van Edwards on Women Of Impact. (L. Bilyeu, Interviewer) Youtube. Retrieved June 29, 2020, from https://www.youtu be.com/watch?v=Ft_5qeI_Z4w

Gordon, H.R. (2007). Allies within and without how adolescent activists conceptualize ageism and navigate adult power in youth social movements. Journal of Contemporary Ethnography, 36, 631-668. https://doi.org/10.1177/089124160629360816.

Gordon, H.R. (2008). Gendered paths to teenage political participation: Parental power, civic mobility, and youth activism. Gender and Society, 22(1), 31-55. Retrieved May 14, from https://www. jstor.org/stable/27641037

Gubar, M. (2009). Artful Dodgers: Reconceiving the Golden Age of Children's Literature. New York: Oxford University Press. Retrieved May 25, 2020, from https://books.google.co.uk/books ?id=cuq8IticJeAC\&printsec $=$ frontcover $\& \mathrm{hl}=$ fr\&source $=$ gbs_ge_summary_r\&cad=0\#v=onepa ge $\& \mathrm{q} \& \mathrm{f}=$ false

Gubar, M. (2013). Risky Business: Talking about Children in Children's Literature Criticism. Children's Literature Association Quarterly, 38(4), 450-457. Retrieved January 16, 2020, from https://musejhu-edu.mmu.idm.oclc.org/article/526079

Hunt, P. (1989). Converging currents: The consequences of the critical. Children's Literature Association Quarterly, 1989(1), 3-13. https://doi.org/10.1353/chq.1989.0011

Joosen, V. (2013, 11). The Adult as Foe or Friend?: Childism in Guus Kuijer's Criticism and Fiction. International Research in Children's Literature, 06(02), 205-217. https://doi.org/10.3366/ ircl.2013.0099

King, A.S. (2016). Still Life with Tornado. Melbourne: The Text Publishing Company. 
Kitchener, C. (2017, 12 1). Why So Many Adults Love Young-Adult Literature. The Atlantic. Retrieved July 14, 2020, from https://www.theatlantic.com/entertainment/archive/2017/12/why-so-many-adult s-are-love-young-adult-literature/547334/\#: :text=Young\%2Dadult\%20literature\%20typically\%20 centers,today's\%20YA\%20readers\%20are\%20adults.

Lesko, N. (2012). Act your age! A cultural construction of adolescence (2 ed.). Routledge. Retrieved July 1, 2020, from https://www.dawsonera.com/readonline/9780203121580

Levesque, R.J. (2011). Externalizing and Internalizing Symptoms. In R.J. Levesque (Ed.), Encyclopedia of adolescence. New York: Springer.

Lipowska, M., Lipowski, M., and Pawlicka, P. (2016). "Daughter and son: a completely different story"? Gender as a moderator of the relationship between sexism and parental attitudes. Health Psychology Report, 4(3), 224-236. https://doi.org/10.5114/hpr.2016.62221.

Manderson, D. (2003). From hunger to love: Myths of the source, interpretation, and constitution of law in children's literature. Law \& Literature, 15(01), 87-141. https://doi.org/10.1525/lal.2003.15.1.87.

Miller, A. (2006). The Body Never Lies: The Lingering Effects of Hurtful Parenting. (A. Jenkins, Trans.) New York: W. W. Norton \& Company. Retrieved May 26, 2020, from https://books.googl e.co.uk/books $? \mathrm{id}=\mathrm{cWJAd} 1$ FyLSIC $\&$ pg $=$ PA43 $\& \mathrm{hl}=$ fr $\&$ source $=$ gbs_toc_r $\&$ cad $=4 \# \mathrm{v}=$ onepa ge\&q=The $\% 20$ tradition $\% 20$ of $\% 20$ sacrificing $\% 20$ children $\% 20 \& \mathrm{f}=$ false

Moore, A. (2018, December 21). "I Knew You Were Trouble": Considering Childism(s), Shame Resilience, and Adult Caretaker Characters Surrounding YA Rape Survivor Protagonists. New Review of Children's Literature and Librarianship, 24(02), 144-166. https://doi.org/10.1080/13614 541.2018.1535778 17

Organization, W.H. (2017). Child Maltreatment. Retrieved May 25, 2020, from https://www.who.int/ violence_injury_prevention/violence/child/Child_maltreatment_infographic_EN.pdf?ua=1

Rudd, D. (2013). Reading the child in children's literature: An heretical approach. London: Palgrave Macmillan.

Ryan, J., and Herringa, R.M. (2013). Childhood maltreatment is associated with altered fear circuitry and increased internalizing symptoms by late adolescence. PNAS, 110(47), 19119-19124. https://doi. org/10.1073/pnas.1310766110.

Smith, A.B. (2011). Respecting Children's Rights and Agency. In D. Harcourt, B. Perry, \& T. Waller (Eds.), In Young Children's Perspectives: Ethics, Theory and Research (pp. 11-25). London: Routledge. Retrieved March 27, 2020, from https://www.dawsonera.com/readonline/9780203830437/ startPage/6/1

Smith-D'Arezzo, W.M., and Thompson, S. (2006). Topics of stress and abuse in picture books for children. Children's Literature in Education, 37, 335-347. https://doi.org/10.1007/s10583-006-9015-3.

Strimel, C.B. (2004). The politics of terror: Rereading Harry Potter. Children's Literature in Education, 35, 35-52. https://doi.org/10.1023/B:CLID.0000018899.06267.11.

Superle, M. (2016). The United Nations Convention on the Rights of the Child: At the Core of a ChildCentered Critical Approach to Children's Literature. The Lion and the Unicorn, 40(02), 144-160. Retrieved April 26, 2020, from https://muse-jhu-edu.mmu.idm.oclc.org/article/628009\#info_wrap

Wall, J. (2019, 09 25). From childhood studies to childism: reconstructing the scholarly and social imaginations. Children's Geographies., https://doi.org/10.1080/14733285.2019.1668912.

World Health Organization: Preventing Child Maltreatment: a guide to taking action and generating evidence. (2006). Retrieved May 3, 2020, from https://apps.who.int/iris/bitstream/handle/10665/43499 19241594365_eng.pdf;jsessionid=B39630FB853CE1E3FF88EFB11B29C958? sequence=1

Young-Bruehl, E. (2012). Childism: Confronting Prejudice Against Children. New Haven and London: Yale University Press.

Zipes, J. (2012). Childism and the Grimms' Fairy Tales or How We Have Happily rationalized Child Abuse through Storytelling. Retrieved May 26, 2020, from https://www.academia.edu/6192577/ Childism_and_Grimms_Tales

Publisher's Note Springer Nature remains neutral with regard to jurisdictional claims in published maps and institutional affiliations.

Nourhene Dziri is a Ph.D. candidate at Manchester Metropolitan University. Her research interests lie in Contemporary Young Adult fiction, adultism and children's rights. 